\title{
Is a Retroaortic Vein a Risk Factor in Laparoscopic Living Donor Nephrectomy?
}

\author{
Josef Mang ${ }^{a} \quad$ Linda Hennig $^{a} \quad$ Nadine Biernath ${ }^{a} \quad$ Lutz Liefeldt $^{b}$ \\ Anna Bichmann ${ }^{c}$ Bernhard Ralla ${ }^{a}$ Andreas Maxeiner $^{a}$ Robert Peters $^{a}$ \\ Hannes Cash ${ }^{a}$ Klemens Budde ${ }^{b}$ Frank Friedersdorffa \\ aDepartment of Urology, Charité - Universitätsmedizin Berlin, corporate member of Freie Universität Berlin, \\ Humboldt-Universität zu Berlin and Berlin Institute of Health, Berlin, Germany; ${ }^{b}$ Department of Nephrology, \\ Charité - Universitätsmedizin Berlin, corporate member of Freie Universität Berlin, Humboldt-Universität zu Berlin \\ and Berlin Institute of Health, Berlin, Germany; ' ${ }^{\mathrm{C}}$ Department of Anesthesiology and Operative Intensive Care \\ Medicine, Campus Charité Mitte, Charité - Universitätsmedizin Berlin, corporate member of Freie Universität Berlin, \\ Humboldt-Universität zu Berlin and Berlin Institute of Health, Berlin, Germany
}

\section{Keywords}

Laparoscopic donor nephrectomy · Retroaortic vein · Vascular anatomy · Surgical complications

\footnotetext{
Abstract

Introduction: In living donor transplantation choosing the right donor and donor side for laparoscopic donor nephrectomy is a challenging task in clinical practice. Knowledge about anomalies in renal blood supply are crucial to evaluate the feasibility of the operative procedure. Few data so far exist whether the existence of a retroaortic left renal vein has an impact on living kidney transplantation outcome for donor and recipient. Materials and Methods: We retrospectively analyzed 221 patients who underwent laparoscopic living donor nephrectomy between 2011 and 2017 for existence of a retroaortic left renal vein. Clinical characteristics and operative outcomes for donors and recipients were an-
}

alyzed. Results: 221 patients underwent donor nephrectomy between 2011 and 2017; 11 patients (4.98\%) showed the feature of a retroaortic left renal vein, and in 8 patients (72.7\%) out of those 11 the left kidney was chosen for transplantation. Mean preoperative serum creatinine was 0.77 (0.49-0.98) $\mathrm{mg} / \mathrm{dL}$ and $1.28(0.97-1.64) \mathrm{mg} / \mathrm{dL}$ at discharge. In recipients mean serum creatinine preoperatively, after 1 week, 1 month, 1 year, 2 and 3 years of follow-up was 10.36 (6.09-20.77) mg/dL, 1.71 (0.67-2.72), 1.33 (0.70-1.89), 1.31 (0.95-2.13), $1.31(0.98-2.13)$ and 1.33 (1.03-1.84), respectively. Neither donors nor recipients suffered from any operative complications. Conclusions: Laparoscopic living donor nephrectomy of a left kidney with retroaortic renal vein is safe for the donor, without limitation in the outcome for the recipient.

(C) 2020 The Author(s) Published by S. Karger AG, Basel

\begin{tabular}{ll}
\hline karger@karger.com & (c) 2020 The Author(s) \\
Published by S. Karger AG, Basel & Karger \\
Targarger.com/uin & This article is licensed under the Creative Commons Attribution- \\
NonCommercial-NoDerivatives 4.0 International License (CC BY- \\
NC-ND) (http://www.karger.com/Services/OpenAccessLicense). \\
Usage and distribution for commercial purposes as well as any dis- \\
tribution of modified material requires written permission.
\end{tabular}




\section{Introduction}

Laparoscopic donor nephrectomy has widely been accepted as standard procedure for living donor transplantation. This is due to patients experiencing less postoperative pain, a shorter hospital stay and earlier return to normal activity compared to open donor nephrectomy $[1,2]$.

Evaluation and identification of the right donor in clinical practice remains a challenging task, including evaluation of operative feasibility of laparoscopic donor nephrectomy. Therefore, anatomical anomalies of renal blood supply play an important role, not only for donor selection, but also for donor anatomical side selection. Renal blood supply varies in number of vascular supply including anatomical course and number of blood vessels present [3]. Data on living donor nephrectomy of kidneys with multiple arteries suggest that there is no higher risk for donor and recipient, although the operative steps are surgically more difficult $[4,5]$. However, so far there is only little evidence regarding the consequence of anatomical course anomalies of the renal vein, especially cases with retroaortic left veins. In this analysis, we aim to discuss results of laparoscopic donor nephrectomies in patients with left-sided retroaortic veins.

\section{Materials and Methods}

\section{Patients}

For the present study all laparoscopic donor nephrectomies performed between 2011 and 2017 at Charité Hospital Berlin, Department for Urology, were analyzed for anatomical variations of the left renal vein. Approval by the Institutional Review Board of Charité Hospital Berlin was not necessary, and the need for informed consent was waived because of this study's retrospective, noninterventional design and because patient data confidentiality and privacy were maintained.

\section{Patient Preparation}

All donors underwent an extensive medical workup to ensure there were no malignancies and chronic diseases. Renal vascular imaging was performed with multislice CT angiography and/or with MR angiography. Donor split renal function was tested using ${ }^{99}$ mTC-MAG3 renography. In cases of a relevant difference between the left and the right donor kidney, the kidney with inferior function was chosen, regardless of the renal vascular anatomy.

\section{Surgical Technique}

Laparoscopic Donor Nephrectomy

For laparoscopic donor nephrectomy, a pure laparoscopic, non-hand-assisted procedure with a 4-port transperitoneal access was used. 12-mm Hem-o-lok and titanium clips were used to secure the arteries. The left renal vein was typically secured with 2 Hem-o-lok clips, and in case of right laparoscopic donor nephrec-

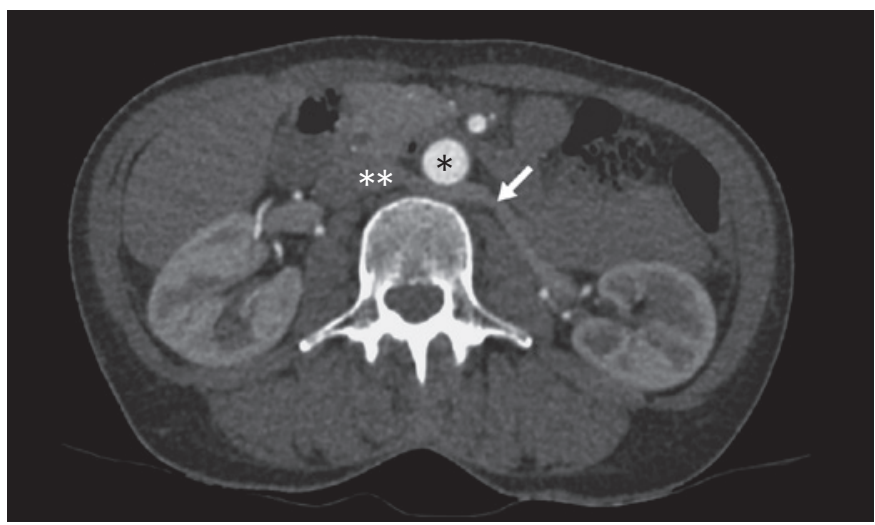

Fig. 1. CT scan of a retroaortic left renal vein. ${ }^{*}$, aorta; ${ }^{* *}$, vena cava; $\rightarrow$, retroaortic left renal vein.

tomy the renal vein was typically secured with an Endo-TA multifire stapler. The extraction of the kidneys was performed via a flank incision of approximately $6 \mathrm{~cm}$ in length, then they were flushed with ice-cold histidine-tryptophan-ketoglutarate solution.

Renal Transplantation

Renal transplantation was performed by the standard extraperitoneal technique. Anastomoses between the renal vessels and the external iliac vessels were performed in an end-to-side technique. For ureteroneocystostomy, a ureteral JJ stent was routinely used. The stent was typically removed 6 weeks after transplantation.

\section{Results}

From 221 patients who underwent laparoscopic donor nephrectomy between 2011 and 2017, 11 (4.98\%) showed the feature of a retroaortic left renal vein (Fig. 1). In 8 patients $(72.7 \%)$ decision for left kidney donor nephrectomy was made.

Detailed information about donors and recipients of these 8 cases are shown in Tables 1 and 2, regarding patient age, sex, body mass index (BMI), cold ischemia time (CIT), warm ischemia time (WIT), time of surgery, complications and serum creatinine at different times. The mean patient characteristics are shown in Table 3.

From donors who featured a retroaortic left vein, 3 (37.5\%) were men and $5(62.5 \%)$ women, with a mean age of 52.88 (41-66) years and a mean BMI of 25.93 (22.1$35.6)$. The mean time of surgery was $231(167-280) \mathrm{min}$ with an average WIT of $116.86(96-150)$ s, whereas in 1 patient WIT was not documented. None of the patients showed postoperative complications higher than Clavien-Dindo grade 1 [6]. Their average hospital duration 
Table 1. Donor characteristics

\begin{tabular}{|c|c|c|c|c|c|c|c|c|c|}
\hline $\begin{array}{l}\text { Age, } \\
\text { years }\end{array}$ & Sex & BMI & $\begin{array}{l}\text { CIT, } \\
\min \end{array}$ & $\begin{array}{l}\text { WIT, } \\
\text { s }\end{array}$ & $\begin{array}{l}\text { Time of } \\
\text { surgery, min }\end{array}$ & $\begin{array}{l}\text { Compli- } \\
\text { cations }\end{array}$ & $\begin{array}{l}\text { Days in } \\
\text { hospital }\end{array}$ & $\begin{array}{l}\text { Serum creatinine } \\
\text { preoperatively, } \\
\mathrm{mg} / \mathrm{dL}\end{array}$ & $\begin{array}{l}\text { Serum creatinine } \\
\text { at discharge, } \mathrm{mg} / \mathrm{dL}\end{array}$ \\
\hline 41 & $\mathrm{~F}$ & 27.9 & 140 & 130 & 190 & 0 & 9 & 0.49 & 0.97 \\
\hline 52 & $\mathrm{~F}$ & 24.3 & 161 & 105 & 210 & 0 & 6 & 0.78 & 1.21 \\
\hline 46 & $\mathrm{~F}$ & 23.5 & 186 & 117 & 245 & 0 & 5 & 0.77 & 1.34 \\
\hline 63 & $\mathrm{~F}$ & 22.1 & 197 & 111 & 247 & 0 & 6 & 0.77 & 1.17 \\
\hline 55 & $\mathrm{M}$ & 27.7 & 215 & 109 & 266 & 0 & 9 & 0.92 & 1.64 \\
\hline
\end{tabular}

BMI, body mass index; CIT, cold ischemia time; WIT, warm ischemia time.

Table 2. Recipient characteristics

\begin{tabular}{|c|c|c|c|c|c|c|c|c|c|c|c|c|}
\hline $\begin{array}{l}\text { Age, } \\
\text { years }\end{array}$ & Sex & BMI & $\begin{array}{l}\text { CIT, } \\
\text { min }\end{array}$ & $\begin{array}{l}\text { Time of } \\
\text { anas- } \\
\text { tomosis, } \\
\text { min }\end{array}$ & $\begin{array}{l}\text { Time } \\
\text { of } \\
\text { surgery, } \\
\text { min }\end{array}$ & $\begin{array}{l}\text { Compli- } \\
\text { cations } \\
\text { (Clavien- } \\
\text { Dindo) }\end{array}$ & $\begin{array}{l}\text { Serum } \\
\text { creatinine } \\
\text { preoperati- } \\
\text { vely, } \mathrm{mg} / \mathrm{dL}\end{array}$ & $\begin{array}{l}\text { Serum creati- } \\
\text { nine } 1 \text { week } \\
\text { past surgery, } \\
\mathrm{mg} / \mathrm{dL}\end{array}$ & $\begin{array}{l}\text { Serum creati- } \\
\text { nine } 1 \text { month } \\
\text { past surgery, } \\
\mathrm{mg} / \mathrm{dL}\end{array}$ & $\begin{array}{l}\text { Serum creati- } \\
\text { nine } 1 \text { year } \\
\text { past surgery, } \\
\mathrm{mg} / \mathrm{dL}\end{array}$ & $\begin{array}{l}\text { Serum creati- } \\
\text { nine } 2 \text { years } \\
\text { past surgery, } \\
\mathrm{mg} / \mathrm{dL}\end{array}$ & $\begin{array}{l}\text { Serum } \\
\text { creatinine } \\
3 \text { years past } \\
\text { surgery, } \\
\mathrm{mg} / \mathrm{dL}\end{array}$ \\
\hline 36 & M & 24.7 & 221 & 45 & 160 & $3 b$ & 10.34 & 2.72 & 1.25 & 1.08 & 1.00 & 1.10 \\
\hline 20 & M & 18.4 & 140 & 33 & 155 & 0 & 13.24 & 1.26 & 1.14 & 0.95 & 1.20 & 1.03 \\
\hline 13 & M & 18.1 & 159 & 25 & 159 & 0 & 6.09 & 0.67 & 0.70 & 0.95 & 0.98 & 1.10 \\
\hline 61 & M & 35.6 & 218 & 42 & 172 & 0 & 11.89 & 2.68 & 1.89 & 2.13 & 2.13 & 1.84 \\
\hline 63 & M & 29.1 & 197 & 34 & 184 & 0 & 7.32 & 1.56 & 1.73 & 1.45 & 1.36 & 1.36 \\
\hline 51 & $\mathrm{~F}$ & 33.6 & 215 & 33 & 151 & 0 & 6.42 & 1.13 & 0.79 & 1.13 & 1.01 & - \\
\hline
\end{tabular}

BMI, body mass index; CIT, cold ischemia time.

Table 3. Patient characteristics: mean (range)

\begin{tabular}{lcc}
\hline & Donor & Recipient \\
\hline Age, years & $52.88(41-66)$ & $40.13(13-63)$ \\
BMI & $25.93(22.1-35.6)$ & $26.43(18.1-35.6)$ \\
CIT, min & & $187.13(140-221)$ \\
WIT, s & $116.86(96-150)$ & \\
Total time of surgery, min & $231(167-280)$ & $167(151-184)$ \\
Time to anastomosis, min & & $37.75(25-45)$ \\
Serum creatinine before surgery, mg/dL & $0.77(0.49-0.98)$ & $10.36(6.09-20.77)$ \\
Serum creatinine 1 week after surgery $($ or at discharge), mg/dL & $1.28(0.97-1.64)$ & $1.71(0.67-2.72)$ \\
Serum creatinine 1 month after surgery, mg/dL & & $1.33(0.70-1.89)$ \\
Serum creatinine 1 year after surgery, mg/dL & & $1.31(0.95-2.13)$ \\
Serum creatinine 2 years after surgery, mg/dL & & $1.31(0.98-2.13)$ \\
Serum creatinine 3 years after surgery, mg/dL & & $1.33(1.03-1.84)$ \\
\hline
\end{tabular}

BMI, body mass index; CIT, cold ischemia time; WIT, warm ischemia time.

Retroaortic Vein: a Risk in Living Donor Nephrectomy? 
was 6.63 days (6-9 days). Overall mean preoperative serum was $0.77 \mathrm{mg} / \mathrm{dL}(0.49-0.98 \mathrm{mg} / \mathrm{dL})$ and $1.28 \mathrm{mg} / \mathrm{dL}$ (0.97-1.64 $\mathrm{mg} / \mathrm{dL})$ at discharge.

Recipients were composed of 7 male $(87.5 \%)$ and 1 female $(12.5 \%)$ patients with a mean age of 40.13 years (1363 years) and a mean BMI of 26.43 (18.1-35.6). Mean CIT was $187.13 \mathrm{~min}$ (140-221 min), mean surgery time for the recipients was $167 \mathrm{~min}$ (151-184 $\mathrm{min}$ ) with an average time of anastomosis of $37.75 \mathrm{~min}$ (25-45 $\mathrm{min})$. One recipient suffered a fascial dehiscence so that an operative revision was necessary.

Mean serum creatinine preoperatively, after 1 week, 1 month, 1, 2 and 3 years of follow-up was 10.36 (6.09$20.77) \mathrm{mg} / \mathrm{dL}, 1.71(0.67-2.72), 1.33$ (0.70-1.89), 1.31 (0.95-2.13), $1.31(0.98-2.13)$ and 1.33 (1.03-1.84), respectively.

\section{Discussion}

The selection of potential donors for living kidney transplantation including the donor side is a complex responsibility. Every potential donor should get preoperative imaging to evaluate kidney anatomy and renal split function [7]. In case there is no relevant side-dependent difference in organ function or other advantages in retaining the left donor kidney, the left kidney is normally favored for transplantation due to the longer renal vein [8]. In the presence of anatomical anomalies, before choosing a side, a risk assessment for the donor and recipient has to be made.

Retroaortic left renal veins are reported to be present in 2-9\% of living kidney donors [9-11]. Our hospital data match these results, with 11 patients (4.98\%) who had a retroaortic left vein. Published research has listed the option to preferably choose a right donor kidney over a left in the presence of a retroaortic vein anomaly $[12,13]$. Recent data from other authors suggest that choosing a left kidney with retroaortic vein is safe with good outcomes for donor and recipient [14-16].

This research shows the results of living donor transplantations of left kidneys with a retroaortic renal vein in Tables $1-3$. From the study cohort, 8 identified patients showed this anatomical feature of whom none suffered any surgical complications. Furthermore, our current WIT, CIT, total time of surgery and transplant function results are all comparable to previously published results from our hospital $[2,17]$. We did not perform any statistical analysis in this case study, since the cohort with 8 patients is very small compared to the overall 221 pa- tients. In 3 cases with a present left-sided retroaortic vein, the right kidney was chosen solely based on the donor's advantage retaining their left kidney.

The operative approach to the renal vein differs slightly in the presence of a retroaortic renal vein, since the vein enters the renal hilum inferiorly making the kidney less mobile. This often caries further anatomical variances including the entrance of lumbar, adrenal and gonadal veins. An advantage of this anatomical variance is the wider gap between the renal artery and vein due to their variable degrees of hilar entrance. The retroaortic renal vein is typically dissected from the lateral aortic border, thereby slightly shortening the total length which still exceeds the length of the right-sided renal vein.

Finally based on our data we conclude that living donor transplantation of a left kidney with a retroaortic vein anomaly can be performed without a higher risk for the donor and without potential disadvantages in transplant function for the recipient. The retrospective analysis as well as the limited number of patients might confound our results.

\section{Conclusions}

The identification and evaluation of a retroaortic left renal vein anomaly with a CT angiography and preoperative preparation is crucial for successful living donor transplantation. A retroaortic renal vein does not impact the perioperative outcome and hence displays no contraindication for donor and organ selection.

\section{Acknowledgment}

We cordially thank Antonia Wolf for carefully reading the paper.

\section{Statement of Ethics}

The data presented in this study were obtained ethically in accordance with the World Health Association Declaration of Helsinki. For retrospective analysis, patients were provided with a waiver with consent information. The study was approved by the ethics committee of Charité - Universitätsmedizin.

\section{Disclosure Statement}

All authors declare that they have no competing interests. 


\section{Funding Sources}

There is no specific founding related to the subject matter of this article.

\section{Author Contributions}

Friedersdorff: designed the research study. Friedersdorff, Peters, Mang, Hennig: acquired the data. Mang, Friedersdorff: analyzed the data. Mang, Friedersdorff: wrote the paper. Biernath, Liefeldt, Bichmann, Ralla, Maxeiner, Peters, Cash, Budde: critically revised the paper.

\section{References}

1 Fonouni H, Mehrabi A, Golriz M, Zeier M, Müller-Stich BP, Schemmer P, et al. Comparison of the laparoscopic versus open live donor nephrectomy: an overview of surgical complications and outcome. Langenbecks Arch Surg. 2014 Jun;399(5):543-51.

2 Friedersdorff F, Kothmann L, Manus P, Roigas J, Kempkensteffen C, Magheli A, et al. Long-Term Donor Outcomes after Pure Laparoscopic versus Open Living Donor Nephrectomy: Focus on Pregnancy Rates, Hypertension and Quality of Life. Urol Int. 2016; 97(4):450-6.

3 Sebastià C, Peri L, Salvador R, Buñesch L, Revuelta I, Alcaraz A, et al. Multidetector CT of living renal donors: lessons learned from surgeons. Radiographics. 2010 Nov;30(7):187590.

4 Al-Oraifi I, Tawfeeq M, Al-Hellow H, AlQahtani MS, Al-Bugami MM, Al-Shahrani A, et al. Laparoscopic Donor Nephrectomy of Dual Renal Artery Kidneys: Single Center Experience. Chirurgia (Bucur). 2017 Mar-Apr; 112(2):124-9.

5 Broudeur L, Karam G, Chelghaf I, De Vergie S, Rigaud J, Perrouin Verbe MA, et al. Feasibility and safety of laparoscopic living donor nephrectomy in case of right kidney and multiple-renal artery kidney: a systematic review of the literature. World J Urol. 2012 Apr; 38(4):919-27.
6 Dindo D, Demartines N, Clavien PA. Classification of surgical complications: a new proposal with evaluation in a cohort of $6336 \mathrm{pa}-$ tients and results of a survey. Ann Surg. 2004 Aug;240(2):205-13.

7 Moore DR, Serur D, Rudow DL, Rodrigue JR, Hays R, Cooper M; American Society of Transplantation. Living Donor Kidney Transplantation: Improving Efficiencies in Live Kidney Donor Evaluation-Recommendations from a Consensus Conference. Clin J Am Soc Nephrol. 2015 Sep;10(9):1678-86.

8 Mandal AK, Cohen C, Montgomery RA, Kavoussi LR, Ratner LE. Should the indications for laparascopic live donor nephrectomy of the right kidney be the same as for the open procedure? Anomalous left renal vasculature is not a contraindiction to laparoscopic left donor nephrectomy. Transplantation. 2001 Mar;71(5):660-4.

9 Schmidt GP, Loeweneck H. Frequency of the retroaortic left renal vein in adults (author's transl). Urol Int. 1975;30(5):332-40. German.

10 Zhu J, Zhang L, Yang Z, Zhou H, Tang G. Classification of the renal vein variations: a study with multidetector computed tomography. Surg Radiol Anat. 2015 Aug;37(6):66775.

11 Sahin C, Kaçira OK, Tüney D. The retroaortic left renal vein abnormalities in cross-sectional imaging. Folia Med (Plovdiv). 2014 JanMar;56(1):38-42.
12 Walker TG, Geller SC, Delmonico FL, Waltman AC, Athanasoulis CA. Donor renal angiography: its influence on the decision to use the right or left kidney. AJR Am J Roentgenol. 1988 Dec;151(6):1149-51.

13 Deák PÁ, Doros A, Lovró Z, Toronyi E, Kovács JB, Végsö G, et al. The significance of the circumaortic left renal vein and other venous variations in laparoscopic living donor nephrectomies. Transplant Proc. 2011 May; 43(4):1230-2.

14 Disick GI, Shapiro ME, Miles RA, Munver R. Critical analysis of laparoscopic donor nephrectomy in the setting of complex renal vasculature: initial experience and intermediate outcomes. J Endourol. 2009 Mar;23(3):451-5.

15 Patil AB, Javali TD, Nagaraj HK, Babu SM, Nayak A. Laparoscopic donor nephrectomy in unusual venous anatomy - donor and recepient implications. Int Braz J Urol. 2017 JulAug;43(4):671-8.

16 Lin CH, Steinberg AP, Ramani AP, Abreu SC, Desai MM, Kaouk J, et al. Laparoscopic live donor nephrectomy in the presence of circumaortic or retroaortic left renal vein. J Urol. 2004 Jan;171(1):44-6.

17 Friedersdorff F, Werthemann $\mathrm{P}$, Cash $\mathrm{H}$, Kempkensteffen C, Magheli A, Hinz S, et al. Outcomes after laparoscopic living donor nephrectomy: comparison of two laparoscopic surgeons with different levels of expertise. BJU Int. 2013 Jan;111(1):95-100. 